\title{
Predation by Predators of the House Fly in Poultry Manure: Effects of Predator Density, Feeding History, Interspecific Interference, and Field Conditions
}

\author{
C. J. GEDEN, ${ }^{1}$ R. E. STINNER, AND R. C. AXTELL \\ Department of Entomology, North Carolina State University, \\ Raleigh, North Carolina 27695
}

\begin{abstract}
Environ. Entomol. 17(2): 320-329 (1988)
ABSTRACT In laboratory assays over a range of predator densities, the range in number of house fly (Musca domestica L.) immatures destroyed per predator per day was as follows: the histerid beetle Carcinops pumilio (Erichson) adults, 21-49; C. pumilio larvae, 13-26; the histerid Dendrophilus xavieri Marseul adults, 5-13; the macrochelid mite Macrocheles muscaedomesticae (Scopoli) females, 10-21; the macrochelid Glyptholapsis confusa (Foá) females, 4-10; the parasitid mite Poecilochirus sp. deutonymphs, 2-5; Poecilochirus sp. females, 2-10; and the muscid fly Ophyra aenescens Weidemann third instars, 7-18. Adult C. pumilio destroyed significantly more house fly immatures per day after $5 \mathrm{~d}$ of starvation $(\bar{x}=104)$ than after $5 \mathrm{~d}$ of feeding $(\bar{x}=25)$; starvation and feeding treatments had no significant effect on predation by $M$. muscaedomesticae and Poecilochirus sp. When C. pumilio adults, M. muscaedomesticae females, and Poecilochirus sp. deutonymphs were tested in various combinations, significant interspecific interference was observed in five of the nine combinations tested and was most pronounced in mixtures of Poecilochirus sp. with C. pumilio. In an experiment in a poultry house with naturally occurring predator populations in manure, estimated mean daily destruction of fly immatures per predator was as follows: C. pumilio adults, 37 ; C. pumilio larvae, $17 ; M$. muscaedomesticae females, 8 ; and Ophyra larvae, 25.
\end{abstract}

KEY WORDS Insecta, house fly, predation, biocontrol

POULTRY PRODUCTION systems, especially cagedlayer houses, often produce high densities of flies of economic, public health, and nuisance importance and have been the target of considerable research into the development and implementation of house fly (Musca domestica L.) integrated pest management programs (Axtell 1986). Naturally occurring predators in the manure are responsible for a large, although unknown, proportion of mortality of house fly immatures and are an essential component of such programs (Axtell 1970, 1981, Legner 1971, Legner et al. 1973, 1975a, Axtell \& Rutz 1986). The use of predators in house fly IPM programs by conservation or augmentation requires an understanding of predator population dynamics and the environmental and biotic factors that influence their effectiveness. Predators of house flies and other filth flies have been surveyed in different types of poultry housing in various regions of the United States, especially North Carolina (Axtell 1970, Pfeiffer \& Axtell 1980), California (Peck \& Anderson 1969, Legner et al. 1975b), and Massachusetts (Geden \& Stoffolano 1987). These studies generally have indicated that the most abundant filth fly predators in poultry manure are the histerid beetle Carcinops pumilio (Erichson), the macrochelid mite Macrocheles muscaedomesticae (Sco-

${ }^{1}$ Current address: Department of Entomology, Cornell University, Ithaca, N.Y. 14853. poli), the uropodid mite Fuscuropoda vegetans (DeGeer), and parasitid mites of the genus Poecilochirus.

Rates of predation by $M$. muscaedomesticae (reviewed by Axtell [1969]) and F. vegetans (O'Donnell \& Axtell 1965, Willis \& Axtell 1968) have been studied extensively under a variety of experimental conditions, with variable results. Comparatively few data are available on predation by C. pumilio (Peck 1969, Morgan et al. 1983) and other members of the manure-inhabiting predator community. The objectives of the present study were to use uniform experimental conditions to determine predation rates at varying predator-prey densities for the histerids C. pumilio and Dendrophilus xavieri Marseul, the macrochelid mites M. muscaedomesticae and Glyptholapsis confusa (Foá), larvae of the muscid fly Ophyra aenescens (Weidemann), and a parasitid mite of the genus Poecilochirus (Wise et al. in press); to determine the effects of starvation and interspecific competition on fly destruction by C. pumilio, M. muscaedomesticae, and Poecilochirus sp.; and to obtain estimates of predation rates in poultry houses for comparison with results observed in the laboratory.

\section{Materials and Methods}

Sources of Predators. Beetle and mite predators were collected in 1986 from poultry houses in Wake 
and Chatham Counties, N.C., and maintained in screen-topped 4 -liter plastic pails $(17 \mathrm{~cm}$ high by $20.5 \mathrm{~cm}$ diameter) filled to a depth of $10 \mathrm{~cm}$ with a 1:1 mixture of fresh poultry manure and prepared fly rearing medium (Ralston-Purina, St. Louis, Mo.). The moisture content of this mixture ranged from 65 to $75 \%$. Frozen house fly eggs were added to the cultures every $2 \mathrm{~d}$, and predators were transferred to fresh medium every 1-3 wk. Live rhabditid nematodes in rearing medium were also added to the mite cultures every $4 \mathrm{~d}$. Ophyra aenescens adults were collected from a poultry house in Wake County, N.C., and were maintained in screen cages on a diet of milk and granulated sucrose. Eggs were collected from tissue paper in the milk dishes and placed in 2-liter screen-topped plastic containers with $1,000 \mathrm{~cm}^{3}$ of the substrate described above. All predator cultures were held in rearing rooms maintained at about $27^{\circ} \mathrm{C}$ with a photoperiod of 12:12 (L:D).

Predation Rates at Varying Predator Densities. Predators were removed from cultures and transferred to screen-topped plastic cups ( $10.7 \mathrm{~cm}$ high; $360 \mathrm{ml}$ capacity) containing $250 \mathrm{~cm}^{3}$ of $1: 1$ poultry manure/fly rearing medium ( $8 \mathrm{~cm}$ deep). Three to six predator density treatments were evaluated for each of the following species and life stages: $C$. pumilio females, males, and second instars (there are only two instars for this species), unsexed $D$. xavieri adults, $M$. muscaedomesticae females, G. confusa females, and Poecilochirus sp. deutonymphs and females. The precise age of the predators at the time of the experiments was not known. Predators were held without prey for $24 \mathrm{~h}$, then $400-500$ fresh ( $<4 \mathrm{~h}$ old) house fly eggs in about $0.7 \mathrm{ml}$ water were pipetted onto the surface of the medium in each cup. In tests with Ophyra larvae, predator density was held constant at 10 third instars per cup and tested with four different fly egg densities: 460, 930, 1,400, and 1,800 eggs per cup. Egg numbers were estimated volumetrically, and the actual number dispensed in a given test was assumed to be the mean of five samples that were pipetted into empty plastic dishes and counted at the same time that the assay cups received eggs. Cups containing medium and fly eggs without predators were used as controls.

Cups were held for $14-20 \mathrm{~d}$ at $27^{\circ} \mathrm{C}$, after which the adult flies were counted, and fly mortality in each cup was calculated by: $(\mathrm{a}-\mathrm{b}) / \mathrm{a}$, where $\mathrm{a}$ is the mean number of eggs introduced and $b$ is the number of flies that emerged. Corrected mortality (Abbott 1925) in each cup containing predators was multiplied by the mean number of eggs introduced to yield the number of flies destroyed by predators for each cup, then this fly destruction was divided by the number of predators present and by the number of days that the house fly immatures were vulnerable to predation, to yield the predation rate (fly immatures destroyed per predator per day). Based on our observations, the prey vulnerability period was about $1 \mathrm{~d}$ for the beetle and mite pred- ators (only eggs and first instars are preyed upon) and $5 \mathrm{~d}$ for Ophyra larvae (all larval instars are preyed upon) under our rearing conditions. Tests were rejected and repeated when control mortality exceeded $30 \%$.

Each test was conducted twice (at least $1 \mathrm{wk}$ apart) using five cups per predator (or prey) density per test, for a total of 10 observations per treatment, plus controls. Predation rates were analyzed by two-way analysis of variance, using treatment, replication (tests 1 and 2), and treatment $\times$ replication as the grouping variables (Proc ANOVA, Statistical Analysis System [SAS Institute 1982]).

Influence of Feeding History on Predation. The influence of predator feeding history on predation rates was evaluated by extracting predators from cultures, transferring them to fresh manure-rearing medium in cups, and subjecting them to the following six feeding treatments: fed on house fly eggs for 5,3 , or $1 \mathrm{~d}$ in succession, or deprived of prey (starved) for 1, 3, or $5 \mathrm{~d}$ in succession. Beetles were preconditioned before placement on feedingstarvation treatments by either starving them for $3 \mathrm{~d}$ (beetles placed on feeding treatments) or feeding them for $3 \mathrm{~d}$ (beetles placed on starvation treatments). Predators were then transferred to assay cups (10 C. pumilio adults and Poecilochirus sp. deutonymphs and females per cup; $20 \mathrm{M}$. muscaedomesticae females per cup), and house fly eggs were added. Between 400 and 500 eggs were added to each cup in the mite tests. In the beetle tests, more eggs were added to each cup in the starved (starved $1 \mathrm{~d}, \bar{x}=708$ eggs; $3 \mathrm{~d}, \bar{x}=968 ; 5 \mathrm{~d}, \bar{x}=$ $1,189)$ than in the fed treatment groups $(\bar{x}=514$ eggs) because initial tests demonstrated that starved beetles destroyed substantially more fly immatures than fed beetles. The low egg dosage of 514 eggs per cup was used in the controls. Cups were held at $27^{\circ} \mathrm{C}$ (two test replications of five cups per treatment, plus controls) until the flies emerged. Predation rates were calculated as described in the previous section and analyzed by two-way ANOVA $($ feeding treatment, replication, treatment $\times$ replication).

Interspecific Interference. Possible competition and interference between predator species was evaluated by comparing fly destruction by C. pumilio adults, $M$. muscaedomesticae females, and Poecilochirus sp. deutonymphs alone and in various combinations. Experiments were conducted by simultaneously testing the total corrected fly destruction (corrected mortality $\times$ eggs introduced) by particular predator treatments both separately and together. Fly destructions observed in the separate predator treatments were added and compared with fly destruction by the same numbers of predators tested together. Total fly destruction was used as the unit of measurement and analysis in these experiments because the predation rate (daily fly destruction per predator) varied depending on the relative proportion of each predator in tests with mixed species. However, predation rates 
were calculated as well and are presented to allow comparison with the other experiments.

The following C. pumilio/M. muscaedomesticae combinations were evaluated: 7:38 (about equal fly destruction), 20:20 (equal numbers, fly destruction by C. pumilio favored), and 5:147 (fly destruction by $M$. muscaedomesticae favored). Because fly destruction by Poecilochirus sp. deutonymphs was relatively low and predation rates decreased with increasing mite density, it was impossible to evaluate mixed-species combinations that greatly favored fly destruction by this mite without using unacceptably low numbers of the other species in the tests. For M. muscaedomesticae/Poecilochirus sp. interactions, M. muscaedomesticae were held constant at 20 mites per cup and tested in combinations with 10,20, and 80 Poecilochirus sp. For C. pumilio/Poecilochirus sp. interactions, the following combinations were used: 5:60 (about equal fly destruction), 10:10 (equal numbers), and 5:120.

Predators were placed in assay cups as before (two test replications of five cups per treatment, plus controls) and starved for $1 \mathrm{~d}$. Fresh house fly eggs then were added at dosages that were appropriate for the particular predator densities used in the tests, and cups were held at $27^{\circ} \mathrm{C}$ until the flies emerged. Differences between expected and observed fly destruction were analyzed using the Kruskal-Wallis test (Kruskal \& Wallis 1952), a nonparametric analysis (Proc NPARIWAY of SAS [SAS Institute 1982]).

Predation Rates Under Field Conditions. An experiment was conducted in an open-sided cagedlayer house in Wake County, N.C., to determine the predation rates of naturally occurring predators in poultry manure. The manure in the house had accumulated for about 2 mo and was known to contain high densities of C. pumilio adults and larvae, M. muscaedomesticae females, and lower levels of Ophyra sp. larvae. Manure samples (250 $\mathrm{cm}^{3}$ ) were scooped from the manure rows and placed in plastic dishes $(6.0 \mathrm{~cm}$ high, $9.3 \mathrm{~cm}$ top diameter, $5.6 \mathrm{~cm}$ bottom diameter) at 0800 hours (EST). The dishes (24 on each of two test dates, 27 May and 16 June) then were returned to the same locations in the manure by pressing them back into the depressions formed when the samples were collected. About $3,000(\bar{x}=2,960)$ fresh house fly eggs were added to each dish $4 \mathrm{~h}$ later (1200 hours [EST]). Five dishes containing an equal volume of manure that had been frozen and thawed to kill existing arthropods were used as controls on both test dates and were held inside a screen cage in the house. Dishes were left in place for $24 \mathrm{~h}$, then transferred to 2.5-liter screen-topped plastic pails to exclude additional predators and prevent emigration of developing fly larvae. The manure samples were extracted through Tullgren funnels into $80 \%$ ethanol $2 \mathrm{~d}$ later, and the arthropods (house fly larvae and predators) present in the samples were counted. The number of flies destroyed in each sample was calculated after adjusting for control mortality (Abbott 1925). Predator abundance and fly destruction data from the two sampling dates were pooled and subjected to multiple linear regression analysis (Proc REG of SAS [SAS Institute 1982]) using the model $\mathrm{Y}=\mathrm{b}_{1} \mathrm{X}_{1}+\mathrm{b}_{2} \mathrm{X}_{2}+\mathrm{b}_{3} \mathrm{X}_{3}+$ $\mathrm{b}_{4} \mathrm{X}_{4}$, where $\mathrm{Y}$ is the number of flies destroyed and $\mathrm{X}_{1}$ through $\mathrm{X}_{4}$ are the numbers of C. pumilio adults and larvae, M. muscaedomesticae females, and Ophyra sp. larvae recovered per sample, respectively. The estimated slope parameters $b_{1}$ through $\mathrm{b}_{4}$ therefore represent the contribution to fly destruction by the four predators, yielding field-derived daily predation rate estimates for C. pumilio and M. muscaedomesticae. For Ophyra, the predation rate was determined by dividing the slope estimate $\mathrm{b}_{4}$ by three to account for the $3 \mathrm{~d}$ of prey vulnerability in this experiment.

\section{Results}

Predation Rates at Varying Predator Densities. Predator density had a significant effect $(P<0.05)$ on predation rates of all predators tested (Table 1). Both males and females of C. pumilio destroyed 48-49 fly immatures per beetle per day at the lowest beetle density of five predators per container, and predation rates decreased to about 21 as beetle densities increased to 20. Larvae (second instars) of C. pumilio destroyed significantly fewer prey per predator with increasing predator density, and the predation rate was twice as high at five larvae per container ( 26 fly immatures destroyed per larva per day) as at 20 predator larvae per container (13). Adults of D. xavieri destroyed 13 flies per beetle per day at the lowest predator density (five beetles per container), and fewer (4-5) at higher densities. Females of $M$. muscaedomesticae destroyed about twice as many flies (21 fly immatures per mite per day) at the lowest density of 10 mites per container as at the higher mite densities of 30 and 40 predators per container (12 and 10 , respectively). Glyptholapsis confusa destroyed $30-50 \%$ as many flies $(4-10)$ as $M$. muscaedomesticae at the three mite densities that were evaluated for this species. Predation rates of Poecilochirus sp. deutonymphs declined from 4.8 to 1.6 over the range of densities tested (10-40). Female Poecilochirus destroyed about twice as many fly immatures as the deutonymphs, and predation rates were four times higher ( 9.8 fly immatures destroyed per mite per day) at the lowest predator density (10) than at the highest density ( 40 mites per container, 2.5 fly immatures per mite per day).

Ophyra larvae (not presented in a table), which were evaluated at a constant density (10 larvae) with varying prey numbers, destroyed $17.6 \pm 5.3$ $(n=10)$ fly immatures per predator per day when prey were abundant (1,400 and 1,800 eggs per container). At lower prey densities (460 and 930 eggs per container), predation rates were $7.1 \pm 2.2$ 
Table 1. Rates of predation on house fly immatures at varying densities of C. pumilio, D. xavieri, M. muscaedomesticae, G. confusa, and Poecilochirus sp.

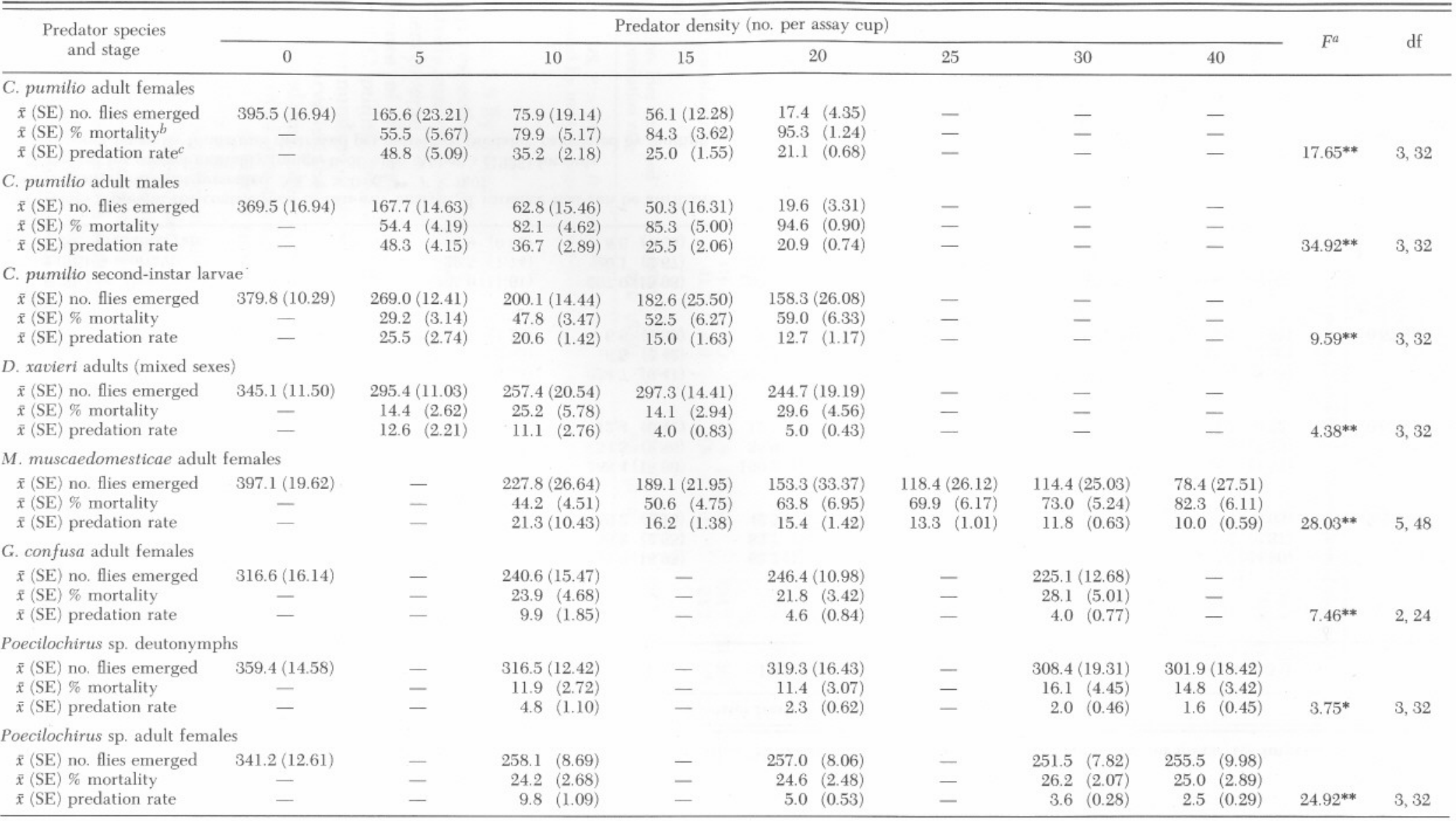

${ }^{a} F$ values represent the contribution to two-way analysis of variance that can be attributed to predator density. Other terms in the ANOVA (replication and replication $\times$ predator density) were not significant and are not presented. NS, $P>0.05 ; *, P \leq 0.05 ; * *, P<0.01$

${ }^{b}$ Corrected for control mortality (range, 11-23\%) by Abbott's (1925) formula.

${ }^{c}$ Number of house fly immatures destroyed per individual predator; calculated by multiplying corrected mortality by the number of fly eggs used in the tests (range, $400-500$ eggs), then dividing this product by the number of predators present in the treatment. 
Table 2. Influence of previous feeding history on rates of predation by $\mathrm{C}$. pumilio, M. muscaedomesticae, and Poecilochirus sp. on house fly immatures

\begin{tabular}{|c|c|c|c|c|c|c|c|c|}
\hline \multirow[b]{2}{*}{ Predator species and stage } & \multicolumn{7}{|c|}{ Predator feeding treatment } & \multirow[b]{2}{*}{$F^{a}$} \\
\hline & $\begin{array}{c}\text { Control } \\
\text { (no predators) }\end{array}$ & Fed $5 \mathrm{~d}$ & Fed $3 \mathrm{~d}$ & Fed $1 \mathrm{~d}$ & Starved $1 \mathrm{~d}$ & Starved $3 \mathrm{~d}$ & Starved $5 \mathrm{~d}$ & \\
\hline \multicolumn{9}{|c|}{ C. pumilio adult (mixed sex, 10 per cup) } \\
\hline $\begin{array}{l}\bar{x}(\mathrm{SE}) \text { no. flies emerged } \\
\bar{x}(\mathrm{SE}) \% \text { mortality } \\
\bar{x}(\mathrm{SE}) \text { predation } \text { rate }^{c}\end{array}$ & $\begin{array}{c}368.4(29.33) \\
- \\
-\end{array}$ & $\begin{array}{r}181.4(22.38) \\
50.0(3.68) \\
25.4 \quad(2.57)\end{array}$ & $\begin{array}{r}147.9(18.95) \\
59.8(2.65) \\
30.2(2.13)\end{array}$ & $\begin{array}{l}62.2(15.43) \\
83.7(3.14) \\
42.5(3.31)\end{array}$ & $\begin{aligned} 124.2(23.83) \\
75.3(4.30) \\
53.0(3.03)\end{aligned}$ & $\begin{array}{cc}180.3 & (26.70) \\
74.1 & (2.99) \\
70.9 & (4.30)\end{array}$ & $\begin{array}{r}102.7(24.80) \\
88.2(2.37) \\
104.2(6.03)\end{array}$ & $149.8^{* * *}$ \\
\hline \multicolumn{9}{|c|}{ M. muscaedomesticae adult females ( 20 per cup) } \\
\hline $\begin{array}{l}\bar{x}(\mathrm{SE}) \text { no. flies emerged } \\
\bar{x}(\mathrm{SE}) \% \text { mortality } \\
\bar{x}(\mathrm{SE}) \text { predation rate }\end{array}$ & $\begin{array}{c}360.2(19.13) \\
- \\
-\end{array}$ & $\begin{array}{r}172.0(23.04) \\
54.0(4.07) \\
12.2(0.68)\end{array}$ & $\begin{array}{r}168.4(18.60) \\
54.5(2.86) \\
12.4(0.41)\end{array}$ & $\begin{array}{r}160.2(14.53) \\
55.9(2.65) \\
12.8(0.61)\end{array}$ & $\begin{array}{r}164.9(26.82) \\
56.3(5.26) \\
12.7(0.97)\end{array}$ & $\begin{array}{r}159.9(20.18) \\
56.9(3.73) \\
13.0(0.63)\end{array}$ & $\begin{array}{r}154.7(14.53) \\
57.5(3.39) \\
13.2(0.72)\end{array}$ & $0.35 \mathrm{NS}$ \\
\hline \multicolumn{9}{|c|}{ Poecilochirus sp. deutonymphs (10 per cup) } \\
\hline $\begin{array}{l}\bar{x}(\mathrm{SE}) \text { no. flies emerged } \\
\bar{x}(\mathrm{SE}) \% \text { mortality } \\
\bar{x}(\mathrm{SE}) \text { predation rate }\end{array}$ & $\begin{array}{c}388.8(21.16) \\
-\end{array}$ & $\begin{array}{rr}344.3 & (11.23) \\
11.4 & (2.89) \\
4.7 & (1.20)\end{array}$ & $\begin{aligned} 324.7 & (9.41) \\
16.5 & (2.42) \\
6.8 & (1.00)\end{aligned}$ & $\begin{array}{r}352.6(12.79) \\
9.3(3.29) \\
3.8(1.36)\end{array}$ & $\begin{array}{r}347.0(10.60) \\
10.8(2.73) \\
4.4(1.13)\end{array}$ & $\begin{array}{r}343.8(16.67) \\
11.6(4.29) \\
4.8(1.78)\end{array}$ & $\begin{array}{rr}345.0 & (8.55) \\
11.3 & (2.20) \\
4.7 & (0.91)\end{array}$ & $0.67 \mathrm{NS}$ \\
\hline \multicolumn{9}{|c|}{ Poecilochirus sp. adult females (10 per cup) } \\
\hline $\begin{array}{l}\bar{x}(\mathrm{SE}) \text { no. flies emerged } \\
\bar{x}(\mathrm{SE}) \% \text { mortality } \\
\bar{x}(\mathrm{SE}) \text { predation rate }\end{array}$ & $\begin{array}{c}371.5(13.43) \\
-\end{array}$ & $\begin{array}{r}295.0(11.61) \\
20.5(1.74) \\
8.9(0.82)\end{array}$ & $\begin{aligned} 297.0 & (15.98) \\
20.1 & (2.67) \\
8.6 & (1.08)\end{aligned}$ & $\begin{array}{r}290.3(15.81) \\
21.8(3.48) \\
9.4(1.51)\end{array}$ & $\begin{array}{r}291.0(11.59) \\
21.3(2.80) \\
9.3(1.33)\end{array}$ & $\begin{array}{r}280.3(15.69) \\
24.7(2.62) \\
10.6(1.17)\end{array}$ & $\begin{array}{r}288.5(19.05) \\
22.6(3.96) \\
9.7(1.60)\end{array}$ & $0.29 \mathrm{NS}$ \\
\hline
\end{tabular}

${ }^{a} F$ values represent the contribution to two-way analysis of variance that can be attributed to feeding treatment $(\mathrm{df}=5,48)$. Other terms in the ANOVA (replication and replication $\times$ predator density) are not presented. NS, $P>0.05 ; * *, P<0.01$.

${ }^{b}$ Corrected for control mortality (range, 6-30\%) by Abbott's (1925) formula. 
Table 3. Predation by $C$. pumilio adults, $M$. muscaedomesticae females, and Poecilochirus sp. deutonymphs on house fly immatures when predators were tested separately and together in different combinations

\begin{tabular}{|c|c|c|c|c|c|}
\hline $\begin{array}{l}\text { Ratio (actual nos.) predator 1/ } \\
\text { predator } 2 \text { used per cup }\end{array}$ & $\begin{array}{c}\text { Predator } 1 \\
\text { tested separately } \\
\text { (A) }\end{array}$ & $\begin{array}{c}\text { Predator } 2 \\
\text { tested separately } \\
\text { (B) }\end{array}$ & $A+B$ & $\begin{array}{l}\text { Predators tested } \\
\text { together } \\
\text { (C) }\end{array}$ & $\mathrm{A}+\stackrel{\chi^{2}}{\mathrm{~B}}$ vs $\mathrm{C}^{a}$ \\
\hline \multicolumn{6}{|c|}{ C. pumilio (predator 1) with M. muscaedomesticae (predator 2) } \\
\hline \multicolumn{6}{|l|}{$7: 38$} \\
\hline $\begin{array}{l}\bar{x}(\mathrm{SE}) \text { no. flies destroyed } \\
\bar{x}(\mathrm{SE}) \text { predation rate }\end{array}$ & $\begin{array}{r}400.1(36.11) \\
57.2(5.16)\end{array}$ & $\begin{array}{rr}449.3 & (41.33) \\
11.8 & (1.09)\end{array}$ & $\begin{array}{rr}849.4 & (65.60) \\
18.9 & (1.46)\end{array}$ & $\begin{array}{r}777.5(34.23) \\
17.2(0.77)\end{array}$ & $\begin{array}{l}0.98 \mathrm{NS} \\
-\end{array}$ \\
\hline \multicolumn{6}{|l|}{$20: 20$} \\
\hline $\begin{array}{l}\bar{x}(\mathrm{SE}) \text { no. flies destroyed } \\
\bar{x}(\mathrm{SE}) \text { predation rate }\end{array}$ & $\begin{array}{r}1,010.5(45.34) \\
50.5 \quad(2.27)\end{array}$ & $\begin{array}{rr}298.7 & (21.75) \\
14.9 & (1.09)\end{array}$ & $\begin{array}{rr}1,309.2 & (60.75) \\
32.7 & (1.52)\end{array}$ & $\begin{array}{r}1,181.5(69.60) \\
29.5(1.74)\end{array}$ & $\begin{array}{l}0.94 \mathrm{NS} \\
-\end{array}$ \\
\hline \multicolumn{6}{|l|}{$5: 147$} \\
\hline $\begin{array}{l}\bar{x}(\mathrm{SE}) \text { no. flies destroyed } \\
\bar{x}(\mathrm{SE}) \text { predation rate }\end{array}$ & $\begin{array}{r}359.4(30.55) \\
71.9(6.11)\end{array}$ & $\begin{array}{rr}1,478.9 & (127.61) \\
10.1 & (0.87)\end{array}$ & $\begin{array}{l}1,838.3(139.22) \\
{\left[\begin{array}{ll}12.1 & (0.92)\end{array}\right]}\end{array}$ & $\begin{array}{rr}1,491.5 & (83.31) \\
9.8 & (0.54)\end{array}$ & $\begin{array}{l}4.22^{*} \\
-\end{array}$ \\
\hline \multicolumn{6}{|c|}{ M. muscaedomesticae (predator 1) with Poecilochirus sp. (predator 2) } \\
\hline \multicolumn{6}{|c|}{ 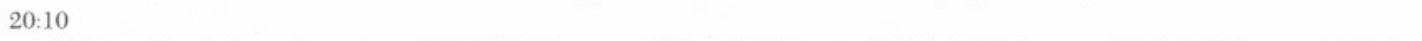 } \\
\hline $\begin{array}{l}\bar{x}(\mathrm{SE}) \text { no. flies destroyed } \\
\bar{x}(\mathrm{SE}) \text { predation rate }\end{array}$ & $\begin{array}{r}247.7(19.88) \\
12.4 \quad(0.99)\end{array}$ & $\begin{array}{rr}67.9 & (12.77) \\
6.8 & (1.28)\end{array}$ & $\begin{array}{rr}315.6 & (30.21) \\
10.5 & (1.01)\end{array}$ & $\begin{array}{r}279.3(17.84) \\
9.3(0.26)\end{array}$ & $\begin{array}{l}0.72 \mathrm{NS} \\
-\end{array}$ \\
\hline \multicolumn{6}{|l|}{$20: 20$} \\
\hline $\begin{array}{l}\bar{x}(\mathrm{SE}) \text { no. flies destroyed } \\
\bar{x}(\mathrm{SE}) \text { predation rate }\end{array}$ & $\begin{array}{r}224.4(19.77) \\
11.1 \quad(0.99)\end{array}$ & $\begin{array}{rr}75.1 & (17.51) \\
3.8 & (0.88)\end{array}$ & $\begin{array}{rr}297.5 & (32.61) \\
7.4 & (0.81)\end{array}$ & $\begin{array}{r}285.1(11.52) \\
7.1 \quad(0.29)\end{array}$ & $\begin{array}{l}0.10 \mathrm{NS} \\
-\end{array}$ \\
\hline \multicolumn{6}{|l|}{$20: 80$} \\
\hline $\begin{array}{l}\bar{x}(\mathrm{SE}) \text { no. flies destroyed } \\
\bar{x}(\mathrm{SE}) \text { predation rate }\end{array}$ & $\begin{array}{r}241.5(22.78) \\
12.1 \quad(1.14)\end{array}$ & $\begin{array}{rr}93.7 & (10.94) \\
1.2 & (0.14)\end{array}$ & $\begin{array}{rr}335.2 & (24.11) \\
3.4 & (0.24)\end{array}$ & $\begin{array}{r}257.4(14.01) \\
2.6(0.14)\end{array}$ & $\begin{array}{l}5.01^{*} \\
-\end{array}$ \\
\hline \multicolumn{6}{|c|}{ C. pumilio (predator 1) with Poecilochirus sp. (predator 2) } \\
\hline \multicolumn{6}{|l|}{$5: 60$} \\
\hline $\begin{array}{l}\bar{x}(\mathrm{SE}) \text { no. flies destroyed } \\
\bar{x}(\mathrm{SE}) \text { predation rate }\end{array}$ & $\begin{array}{r}201.6(16.01) \\
40.3 \quad(3.20)\end{array}$ & $\begin{array}{rr}180.8 & (17.75) \\
3.0 & (0.29)\end{array}$ & $\begin{array}{rr}382.4 & (24.16) \\
5.9 & (0.37)\end{array}$ & $\begin{array}{r}210.6(23.98) \\
3.2(0.37)\end{array}$ & $\begin{array}{l}10.32^{* *} \\
-\end{array}$ \\
\hline \multicolumn{6}{|l|}{$10: 10$} \\
\hline $\begin{array}{l}\bar{x}(\mathrm{SE}) \text { no. flies destroyed } \\
\bar{x}(\mathrm{SE}) \text { predation rate }\end{array}$ & $\begin{array}{r}416.8(14.32) \\
41.7(1.43)\end{array}$ & $\begin{array}{rr}67.9 & (13.33) \\
6.8 & (1.33)\end{array}$ & $\begin{array}{rr}484.7 & (21.36) \\
24.2 & (1.07)\end{array}$ & $\begin{array}{c}322.1(34.46) \\
16.1 \quad(1.72)\end{array}$ & $\begin{array}{l}8.87^{* * *} \\
-\end{array}$ \\
\hline \multicolumn{6}{|l|}{$5: 120$} \\
\hline $\bar{x}(\mathrm{SE})$ no. flies destroyed & $202.9(17.53)$ & $98.0(23.87)$ & $300.9(32.50)$ & $152.7(12.72)$ & $10.45^{* * *}$ \\
\hline$\tilde{x}(\mathrm{SE})$ predation rate & $40.6 \quad(3.51)$ & $0.8 \quad(0.19)$ & $2.4 \quad(0.26)$ & $1.2(0.01)$ & - \\
\hline
\end{tabular}

${ }^{a} \mathrm{df}=1$. NS, $P>0.05 ;{ }^{*}, P<0.05 ;{ }^{* *}, P<0.01 ;$ Kruskal-Wallis test.

${ }^{b}$ Calculated by multiplying corrected (Abbott 1925) mortality (control mortality range, 12-25\%) by the number of eggs used in the test.

and $13.1 \pm 3.8 \mathrm{fly}$ immatures destroyed per larva per day, respectively, although 90 and 220 flies, respectively, emerged from these low-prey-density containers (overall $\bar{x}=13.8$ ).

Influence of Feeding History on Predation. Adults of C. pumilio destroyed significantly $(P<$ 0.01 ) greater numbers of house fly immatures after periods of starvation than after periods of feeding (Table 2). Predation rates ranged from $25 \mathrm{fly}$ immatures destroyed per predator per day among beetles fed for $5 \mathrm{~d}$ before testing to 104 among beetles starved for $5 \mathrm{~d}$.

In contrast, no significant feeding treatment effects $(P>0.05)$ were observed for $M$. muscaedomesticae females. Predation rates after all feeding and starvation treatments fell within a narrow range (12-13 fly immatures destroyed per mite per day). Similar results were observed with Poecilochirus sp.; neither the deutonymphs nor the females destroyed significantly different numbers of fly immatures in response to feeding or starvation treatments.
Interspecific Interference. Results of predator interaction tests are presented in Table 3. Although fly destruction was used in the analyses, predation rates also are presented in the table to allow comparison with previous experiments. No significant interference was observed between C. pumilio and M. muscaedomesticae when there were either fewer mites than beetles or equal numbers of both, but when five beetles were tested with 147 mites, the predators together destroyed significantly $(P<$ 0.05 ) fewer fly immatures than expected based on the sum of flies destroyed by predators tested separately. Similar results were obtained with combinations of $M$. muscaedomesticae and Poecilochirus sp.; significant interference was observed only when substantially more Poecilochirus sp. deutonymphs were present than $M$. muscaedomesticae.

Predation by combinations of C. pumilio with Pôcilochirus sp. was significantly lower $(P<0.01)$ than expected in all three combinations of the beetles and mites. Observed fly destruction was 45,34 , 
and $50 \%$ lower than expected in the 5:60, 10:10, and 5:120 combinations, respectively.

Visual observations of predator behavior also were made in the assay cups. Both C. pumilio and $M$. muscaedomesticae were relatively slow in their movements and often spent up to a minute handling an individual fly egg before destroying it, whereas Poecilochirus sp. deutonymphs moved very rapidly over the prey and other predators in the containers and were rarely observed feeding. When C. pumilio and $M$. muscaedomesticae were held together, the predators generally moved away from each other slightly after making initial contact, but this did not appear to affect substantially the foraging behavior of either. In contrast, the Poecilochirus sp. deutonymphs, because of their rapid and persistent movements, often caused the C. pumilio to drop the egg they were handling, forcing them to begin handling a new one. This effect was not observed in combinations of Poecilochirus sp. with M. muscaedomesticae.

Predation Rates Under Field Conditions. When $48250-\mathrm{cm}^{3}$ samples of manure under caged laying hens were inoculated with ca. 3,000 fly eggs, an average of 1,301 larvae were recovered. After correcting for control mortality $(18.9 \%)$, about 1,700 fly immatures were destroyed per sample (Table 4). These samples contained an average of $22 \mathrm{C}$. pumilio adults, 11 C. pumilio larvae, $27 \mathrm{M}$. muscaedomesticae females, and 4 Ophyra third instars (mostly O. aenescens). No Poecilochirus sp., G. confusa, or D. xavieri were recovered. Estimates of field-derived daily predation rates were $37.1 \mathrm{fly}$ immatures destroyed per C. pumilio adult, 16.9 per C. pumilio larva, 7.5 per M. muscaedomesticae female, and 25.0 per Ophyra sp. third-instar larva.

\section{Discussion}

The predation rates of C. pumilio adults in this study are in general agreement with the results of Peck (1969) and Toyama \& Ikeda (1976). Morgan et al. (1983) conducted a 48-d experiment in which beetles were presented with an abundance of prey daily (150 eggs per beetle), and found that both male and female beetles consumed only about 13 fly eggs per day. This figure is somewhat lower than our lowest observed predation rate, and this may be due to the use of frozen rather than live fly eggs in their study, which eliminated the contribution to fly destruction by beetles feeding on newly hatched fly larvae.

The sexes of C. pumilio did not differ significantly in their predation rates. Males may require high levels of nutritional input to maintain spermatophore production (Geden 1984).

The predation rates of adult C. pumilio varied with changes in feeding history, with rates ranging from 25 fly immatures destroyed per predator per day among beetles fed for $5 \mathrm{~d}$ in succession, to 104 among beetles starved for $5 \mathrm{~d}$. It is unlikely that
Table 4. Density of naturally occurring predators of house fly immatures recovered from $250-\mathrm{cm}^{3}$ manure samples, and predation rates estimated by multiple linear regression analysis. Model $Y=b_{1} x_{1}+b_{2} x_{2}+b_{3} x_{3}+b_{4} x_{4}$, where $\mathrm{Y}$ is the correeted fly destruction by combined predators

\begin{tabular}{lcc}
\hline \hline & $\begin{array}{c}\bar{x} \text { no. (SE) } \\
\text { per 250-cm } \\
\text { sample } \\
\left(\mathrm{x}_{1}-\mathrm{x}_{4}\right)\end{array}$ & $\begin{array}{c}\text { Predation rate (SE) } \\
\left.\text { (estimates of } \mathrm{b}_{1}-\mathrm{b}_{4}\right)\end{array}$ \\
\hline $\begin{array}{l}\text { C. pumilio adults } \\
\text { C. pumilio larvae }\end{array}$ & $21.6(3.19)^{a}$ & $37.1(5.54)$ \\
M. muscaedomesticae & $10.9(2.48)$ & $16.9(9.90)$ \\
females & $26.9(4.05)$ & $7.5(5.28)$ \\
Ophyra sp. third instars & $4.1(1.03)$ & $25.0(7.06)^{b}$ \\
& & $R^{2}=0.85, P<0.001$ \\
\hline
\end{tabular}

${ }^{a} n=24$ samples on each of two occasions. Corrected fly destruction $\mathrm{Y}=1,689.4 \pm 138.87 \mathrm{fly}$ immatures per sample out of $2,960.6 \pm 96.78$ eggs introduced. Control mortality, $18.9 \%$.

${ }^{b}$ Ophyra slope estimate was divided by three to account for the three days that house fly immatures were vulnerable to predation by these predators.

beetles in the field are sufficiently sated for such low predation rates to prevail very often, and our field experiments indicate that a rate in the low to middle range of predation potential, about 37 , is a closer approximation of natural feeding. The highest rate of 104 after $5 \mathrm{~d}$ of starvation is also unlikely to occur in the field, because of the presence of alternative dipteran and acarine prey (Geden \& Stoffolano 1987), and because beetles that are completely deprived of prey disperse from the local environment after 3-4 d of starvation (Geden et al. 1987).

There is very little information on predation by C. pumilio larvae. Peck (1969) observed a second instar predation rate of 27.0 (32.8 when corrected for control mortality) at five predators per container, which is close to our observed rate of 25.5 fly immatures destroyed per larva per day at this predator density. In the field experiment, where beetle larvae were present at 11 predators per 250 $\mathrm{cm}^{3}$ of manure (the same volume as in laboratory tests), a predation rate of 17 was estimated, which agrees with the laboratory-derived rate of 15 at this approximate density. Larval C. pumilio densities are commonly in the range of 15 to 20 per $250 \mathrm{~cm}^{3}$ in manure after long accumulation times (Geden \& Stoffolano 1987), and predation at these densities is presumably lower.

Predation rates of $M$. muscaedomesticae ranged from 10 to 21 fly immatures destroyed per mite per day throughout all laboratory experiments and treatments and appeared to be most sensitive to changes in predator density. No significant predation effects attributable to feeding history were observed. Rodriguez \& Wade (1961) found no consistent trend among mites subjected to two different starvation treatments on a variety of substrates. Published reports of predation rates by M. muscaedomesticae vary widely (reviewed by Axtell [1969]) and range from 2.3 (Singh et al. 1966) to 
34.1 (Rodriguez \& Wade 1961) fly immatures destroyed per mite per day. Higher rates $(>10)$ generally have been observed in animal manure and fly rearing medium (Rodriguez \& Wade 1961, Wallwork \& Rodriguez 1963, Willis \& Axtell 1968, Peck 1969) than on absorbent cotton and paper substrates (Axtell 1961, O’Donnell \& Axtell 1965, Kinn 1966, Toyama \& Ikeda 1976). There is also considerable variation depending on the type of manure or medium that is used as a substrate (Rodriguez \& Wade 1961), and this may be related to the presence of chemical stimuli that elicit higher rates of prey destruction (Wallwork \& Rodriguez 1963).

Estimated M. muscaedomesticae predation rates under field conditions were lower (7.5) than expected based on laboratory results (13.3) at comparable mite densities. Lower rates of fly destruction in simulated field settings have been reported by others (Axtell 1963a, Singh et al. 1966, Rodriguez et al. 1970); they may be caused by the presence of alternative prey. Saprophytic nematodes in animal manure are suitable prey for this mite; their presence may deflect some predation from house fly immatures (Rodriguez et al. 1962, Filipponi \& di Delupis 1963, Ito 1971, 1973, 1977).

Predation by $G$. confusa ranged from 4 to 10 fly immatures per mite per day, and these rates were similar to those obtained by Axtell (1961) and Peck (1969), who observed rates of 9.9 and 7.3 , respectively. Because this species is more common in horse and cow manure than in poultry manure and generally is most abundant in manure of very long accumulation times (Axtell 1963b, Rodriguez et al. 1970), it is probably of minor importance in regulating house fly populations in most cagedlayer houses.

Deutonymphs of Poecilochirus sp. were relatively inefficient predators; their predation rate fell to barely detectable levels with increasing mite densities. Parasitids are most abundant in fresh manure and are most commonly collected in the weeks after manure cleanout (Axtell 1970). Because parasitids appear to prey mainly on newly hatched fly larvae (Wise \& Axtell 1969, Ito 1971, 1977), they may complement the predatory activity of C. pumilio and $M$. muscaedomesticae, which primarily attack eggs (Peck 1969, Toyama \& Ikeda 1976). However, our data suggest that in spite of their predatory nature, the contribution of Poecilochirus sp. to fly control is probably modest. Indeed, data presented in Table 3 indicate that their presence may result in a net loss of fly destruction because of interference with other predators. These mites also may have a negative impact on the population dynamics of more beneficial predators by preying on the immatures of the latter, as occurs in mixed populations of Parasitus coleoptorum (L.) and Macrocheles glaber (Müller) (Ignatowicz 1974).

Third instars of Ophyra aenescens destroyed between 7 and 18 house fly immatures per predator per day in the laboratory, and the field-derived estimate of 25 is not far out of this range. Peck (1969) observed that $O$. leucostoma larvae destroyed $30.6 \mathrm{fly}$ immatures per predator (about six per day) using methods similar to ours; however, this is undoubtedly an underestimate because almost no flies $(0.1)$ emerged from the predator-treated containers in that experiment. Other reported daily predation rates of Ophyra are 4-7 for $O$. capensis (Olckers \& Hulley 1984) and 2-20 for $O$. leucostoma (Anderson \& Poorbaugh 1964).

Ophyra spp. often are very abundant in poultry houses and sometimes are the dominant muscoid fly species present (Nolan \& Kissam 1985, Lysyk \& Axtell 1986). Although some have proposed massrearing and releasing these flies for house fly control (Nolan \& Kissam 1985), it remains to be established that Ophyra do not pose substantial public health or nuisance problems.

The arthropod community structure in poultry manure is complex, and it is difficult to make a priori judgments of fly control potential simply by counting and cataloging predator abundance. Natural rates of predation are likely to vary with temperature, house fly density, maturity and stability of the manure habitat, and with the presence and relative acceptability of alternative dipteran, acarine, and nematode prey (Geden \& Axtell in press). Our laboratory and field results indicate that reasonable estimates of daily fly destruction by key predators are 30-50 and 10-20 fly immatures per C. pumilio adult and larva, respectively, 5-15 per M. muscaedomesticae female, and 10-25 per Ophyra sp. third instar. Our results also demonstrate that laboratory-derived rates of predation can resemble rates occurring under field conditions and can provide baseline data for future investigations into other factors that impinge on the effectiveness of predators in regulating house fly populations.

\section{Acknowledgment}

The authors thank T. D. Edwards for assisting in this study. This is Paper No. 11013 of the Journal Series of the North Carolina Agricultural Research Service, Raleigh, N.C. This research was supported in part by USDACooperative States Research Service Grant No. 86-CRSR2-2889.

\section{References Cited}

Abbott, W. S. 1925. A method for computing the effectiveness of an insecticide. J. Econ. Entomol. 18: 265-267.

Anderson, J. R. \& J. H. Poorbaugh. 1964. Biological control possibilities for house flies. Calif. Agric. 18(9): $2-4$.

Axtell, R. C. 1961. New records of North American Macrochelidae (Acarina: Mesostigmata) and their predation rates on the house fly. Ann. Entomol. Soc. Am. 54: 748 .

1963a. Effect of Macrochelidae (Acarina: Mesostigmata) on house fly production from dairy cattle manure. J. Econ. Entomol. 56: 317-321. 
1963b. Acarina occurring in domestic animal manure Ann. Entomol. Soc. Am. 56: 628-633.

1969. Macrochelidae as biological control agents for synanthropic flies, pp. 401-416. In G. O. Evans [ed.], Proceedings, 2nd International Congress of Acarology. Akadémiai Kiadó, Budapest.

1970. Integrated fly-control program for caged-poultry houses. J. Econ. Entomol. 63: 400-405.

1981. Use of predators and parasites in filth fly IPM programs, pp. 26-43. In R. S. Patterson, P. G. Koehler, P. B. Morgan \& R. L. Harris [eds.], Status of biological control of filth flies. U.S. Dep. Agric,, Agric. Res. Serv. SEA A106.2:F64.

1986. Status of potential of biological control agents in livestock and poultry pest management systems, pp. 1-9. In R. S. Patterson \& D. A. Rutz [eds.], Biological control of muscoid flies. Entomol. Soc. Am. Misc. Publ. No. 62.

Axtell, R. C. \& D. A. Rutz. 1986. Role of parasites and predators as biological fly control agents in poultry production facilities, pp. 88-100. In R. S. Patterson \& D. A. Rutz [eds.], Biological control of muscoid flies. Entomol. Soc. Am. Misc. Publ. No. 62

Filipponi, A. \& G. D. di Delupis. 1963. On the food habits of some macrochelids (Acari: Mesostigmata) associated in the field with synanthropic flies. Riv. Parassitol. 24: 277-288.

Geden, C. J. 1984. Population dynamics, spatial distribution, dispersal behavior and life history of the predaceous histerid, Carcinops pumilio (Erichson), with observations of other members of the poultry manure arthropod community. Ph.D. dissertation, University of Massachusetts, Amherst.

Geden, C. J. \& R. C. Axtell. In press. Predation by Carcinops pumilio (Coleoptera: Histeridae) and Macrocheles muscaedomesticae (Acarina: Macrochelidae) on the house fly (Diptera: Muscidae): functional response, and effects of temperature and availability of alternative prey. Environ. Entomol.

Geden, C. J. \& J. G. Stoffolano, Jr. 1987. Succession of manure arthropods at a poultry farm in Massachusetts, USA, with observations on Carcinops pumilio (Coleoptera: Histeridae) sex ratios, ovarian condition, and body size. J. Med. Entomol. 24: 214-222.

Geden, C. J., J. G. Stoffolano, Jr., \& J. S. Elkinton. 1987. Prey-mediated dispersal behavior of Carcinops pumilio (Coleoptera: Histeridae). Environ. Entomol. 16: 415-419.

Ignatowicz, S. 1974. Inter- and intraspecific competition in mites: Parasitus coleoptorum (L.) and Macrocheles glaber (Müller), pp. 623-625. In E. Piffl [ed.], Proceedings, 4th International Congress of Acarology. Akadémiai Kiadó, Budapest.

Ito, Y. 1971. Predation by manure-inhabiting mesostigmatids (Acarina: Mesostigmata) on some free-living nematodes. Appl. Entomol. Zool. 6: 51-56.

1973. The effects of nematode feeding on the predatory efficiency for house fly eggs and reproduction rate of Macrocheles muscaedomesticae (Acarina: Mesostigmata). Jpn. J. Sanit. Zool. 23: 209-213.

1977. Predatory activity of mesostigmatid mites (Acarina: Mesostigmata) for house fly eggs and larvae under feeding of nematodes. Jpn. J. Sanit. Zool. 28: 167-173.

Kinn, D. N. 1966. Predation by the mite, Macrocheles muscaedomesticae (Acarina: Mesostigmata), on three species of flies. J. Med. Entomol. 3: 155-158.

Kruskal, W. H. \& W. A. Wallis. 1952. Use of ranks in one-criterion variance analysis. J. Am. Stat. Assoc. 47: 583-621.

Legner, E. F. 1971. Some effects of the ambient arthropod complex on the density and potential parasitization of muscoid Diptera in poultry wastes. J. Econ. Entomol. 64: 111-113.

Legner, E. F., W. R. Bowen, W. D. McKeen, W. F. Rooney \& R. F. Hobza. 1973. Inverse relationship between mass of breeding habitat and synanthropic fly emergence and the measurement of population densities with sticky tapes in California inland valleys. Environ. Entomol. 2: 199-205.

Legner, E. F., W. R. Bowen, W. F. Rooney, W. D. MeKeen \& G. W. Johnston. 1975a. Integrated fly control on poultry ranches. Calif. Agric. 29(5): 8-10.

Legner, E. F., G. S. Olton, R. E. Eastwood \& E. J. Dietrick. 1975b. Seasonal density, distribution and interactions of predatory and scavenger arthropods in accumulating poultry wastes in coastal and interior southern California. Entomophaga 20: 269-283.

Lysyk, T. J. \& R. C. Axtell. 1986. Field evaluation of three methods for monitoring populations of house flies (Musca domestica) (Diptera: Muscidae) and other filth flies in three types of poultry housing. J. Econ. Entomol. 79: 144-151.

Morgan, P. B., R.S. Patterson \& D. E. Weidhaas. 1983.A life history study of Carcinops pumilio Erichson (Coleoptera: Histeridae). J. Ga. Entomol. Soc. 18: 353359.

Nolan, M. P., III, \& J. B. Kissam. 1985. Ophyra aenescens: a potential bio-control alternative for house fly control in poultry houses. J. Agric. Entomol. 2: 192-195.

O'Donnell, A. E. \& R. C. Axtell. 1965. Predation by Fusuropoda vegetans (Acarina: Uropodidae) on the house fly (Musca domestica). Ann. Entomol. Soc. Am. 58: 403-404.

Olckers, T. \& P. E. Hulley. 1984. Facultative predation of house fly larvae by larvae of Ophyra capensis. J. Entomol. Soc. South Afr. 47: 231-237.

Peck, J. H. 1969. Arthropod predators of immature Diptera developing in poultry droppings in northern California. Part II. Laboratory studies on feeding behavior and predation potential of selected species. J. Med. Entomol. 6: 168-171.

Peck, J. H. \& J. R. Anderson. 1969. Arthropod predators of immature Diptera developing in poultry droppings in northern California. Part I. Determination, seasonal abundance and natural cohabitation with prey. J. Med. Entomol. 6: 163-167.

Pfeiffer, D. G. \& R. C. Axtell. 1980. Coleoptera of poultry manure in caged layer houses in North Carolina. Environ. Entomol. 9: 21-28.

Rodriguez, J. G. \& C. F. Wade. 1961. The nutrition of Macrocheles muscaedomesticae (Acarina: Macrochelidae) in relation to its predatory action on the house fly egg. Ann. Entomol. Soc. Am. 54: 782-788.

Rodriguez, J. G., C. F. Wade \& C. N. Wells. 1962. Nematodes as a natural food for Macrocheles muscaedomesticae (Acarina: Macrochelidae), a predator of the house fly egg. Ann. Entomol. Soc. Am. 55: 507511.

Rodriguez, J. G., P. Singh \& B. Taylor. 1970. Manure mites and their role in fly control. J. Med. Entomol. 7: 335-341

SAS Institute. 1982. SAS user's guide: statistics. SAS Institute, Cary, N.C.

Singh, P., E. W. King \& J. G. Rodriguez. 1966. Bi- 
ological control of muscids as influenced by host preference of Macrocheles muscaedomesticae (Acarina: Mesostigmata). J. Med. Entomol. 3: 78-81.

Toyama, G. M. \& J. K. Ikeda. 1976. An evaluation of fly predators at animal farms on leeward and central Oahu. Proc. Hawaii Entomol. Soc. 22: 369-379.

Wallwork, J. H. \& J. G. Rodriguez. 1963. The effect of ammonia on the predation rate of Macrocheles muscaedomesticae (Acarina: Macrochelidae) on house fly eggs. Adv. Acarol. 1: 60-69.

Willis, R. R. \& R. C. Axtell. 1968. Mite predators of the house fly: a comparison of Fuscuropoda vegetans and Macrocheles muscaedomesticae. J. Econ. Entomol. 61: 1669-1674.
Wise, G. U. \& R. C. Axtell. 1969. Predation by Poecilochirus sp. (Acarina: Parasitidae) on immature stages of the house fly. J. Elisha Mitchell Sci. Soc. 85(4): 122 .

Wise, G. U., M. K. Hennessey \& R. C. Axtell. In press. A new species of a manure-inhabiting mite in the genus Poecilochirus (Acari: Mesostigmata: Parasitidae) predacious on house fly eggs and larvae. Ann. Entomol. Soc. Am.

Received for publication 24 April 1987; accepted 23 October 1987. 